\title{
elyra
}

\section{Infância, poesia e colagem em Jorge de Lima}

\section{Francisco Thiago Camêlo \\ PUC-Rio}

Resumo: O presente artigo investiga a infância como operador conceitual da obra poética e visual de Jorge de Lima (1893-1953). Em diálogo com o pensamento de Aby Warburg, Georges Didi-Huberman, Gilles Deleuze, Giorgio Agamben, Jean-François Lyotard e Walter Benjamin, comenta cantos selecionados de Invenção de Orfeu (1952) e algumas fotomontagens de A pintura em pânico (1943). Ao indicar as técnicas do recorte e da colagem como procedimentos afinados com o imaginário da infância, considera a escrita verbal e plástica de Jorge de Lima como uma colagem de imagens e tempos heterogêneos feita por um poeta contaminado por gestos infantis.

Palavras-chave: Jorge de Lima, infância, poesia, colagem, recorte, artes plásticas

\begin{abstract}
This article investigates the childhood as conceptual operator of the poetic and visual work of Jorge de Lima (1893-1953). In dialogue with the philosophical propositions of Aby Warburg, Georges Didi-Huberman, Gilles Deleuze, Giorgio Agamben, Jean-François Lyotard and Walter Benjamin remarks selected tales of Invenção de Orfeu (1952) and some photomontages of A pintura em pânico (1943). Indicating the cotout and collage techniques as honed procedures like the childhood imaginary, considers the verbal and visual work of Jorge de Lima like a collage of heterogeneous images and periods made from a poet contaminated by children's gestures.
\end{abstract}

Keywords: Jorge de Lima, childhood, poetry, collage, cutouts, visual arts 
Ruim memória, houve um tempo prenatal (Como sangra pensar com esta memória!) Jorge de Lima

Posso sonhar como no passado aprendi a andar. Mas isso de nada adianta. Hoje sei andar, porém, nunca mais poderei tornar a apreendê-lo. Walter Benjamin

Perdidas as memórias do "tempo prenatal", como fazer uma experiência de escrita e pensamento com a infância? $O$ que significa ter sido um dia infante ${ }^{1}$ O que acontece na passagem entre mudez e eclosão da fala? Um dos pressupostos mais disseminados pela linguística moderna e pela filosofia é o de que, ao contrário dos animais que já nascem com suas habilidades fônicas desenvolvidas, os humanos precisam saltar de uma dimensão aquém da língua para o discurso articulado. Não nascemos já falando, assim como o gato já nasce miando ou o cachorro já nasce latindo. Diante dessa constatação, poder-se-ia pensar em restos ou "sobrevivências" da experiência muda na língua articulada dos adultos? E se tais resíduos existissem, como a arte, verbal ou plástica, grafaria essa experiência a que só aqueles que não possuem uma língua estruturada têm acesso? Através de uma escrita tateante propõe-se, aqui, tentar flagrar o nascimento de uma "infância da linguagem" em dois experimentos do poeta Jorge de Lima (1893-1953). Enquanto os ouvidos se põem alertas para escutar sons desordenados emitidos por infantes, os olhos tentam flagrar instantâneos de conhecimento produzido por uma língua menor ainda não domesticada. Para a tarefa de trazer para o agora um tempo longínquo e imemorial, encena-se o contágio de vozes da criação artística e do pensamento filosófico. Adverte-se que escrever com a infância não significa, aqui, verticalizar esta ou aquela teoria, mas abrir entre elas canais de contato e passagem por onde possa circular uma infância tomada como "personagem conceitual"2 da obra verbal e visual de Jorge de Lima. 


\section{CENA 1: CRIANÇA BRINCANDO}

Sentado no chão, o menino retira do lixo revistas, catálogos, postais, cartões, e folheia com atenção os materiais simples e diversificados. Do contato sensível com a textura do papel, surge a paixão do recorte. Com lápis e tesoura nas mãos, ele traça o contorno das figuras, desenha trajetos nas páginas e recorta gravuras de animais, estátuas gregas, objetos do cotidiano, imagens de mulheres, crianças e algumas paisagens, conferin do a cada recorte um gozo celestial. Envolto em prazer, percebe uma sintaxe secreta entre as gravuras recortadas, inacessível a quem tenta ver de cima o momento em que os recortes se desprendem de sua imagem habitual para ganharem, pela colagem, uma outra forma sensível. O que conhecemos do menino são o gesto rebelde de destruir "os brinquedos perfeitos que os vovôs lhe deram" e sua irresistível atração por coisas e objetos menos nobres, como sabugos de milho, caixas vazias e pedrinhas brancas. A esses brinquedos fabricados com materiais rudimentares vêm juntar-se as novas invenções do menino, criadas com o lápis, a tesoura e a cola. E assim ele vai povoando seu mundo com coisas impossíveis. ${ }^{3}$

\section{CENA 2: PENSANDO A INFÂNCIA}

A brincadeira do recorte, da seleção e da colagem é indicadora daquilo que as crianças não param de fazer: explorar as potencialidades entre materiais distintos para estabelecer entre eles uma nova relação. Walter Benjamin, no belo texto "Canteiro de obra", do livro Rua de mão única, destaca a capacidade infantil de construir superinvenções com materiais descartados e pontifica que a sensibilidade infantil está afinada com o lugar dos escombros. Segundo o pensador alemão, brincando com as coisas descartadas pelos adultos e explorando-as inventivamente, "as crianças criam para si seu mundo de coisas, um pequeno no grande, elas mesmo." (2012b: 17)

Por não serem construídas logicamente, segundo o ideal moderno de conhecimento (conhecer é objetivar), as invenções produzidas pelas crianças no "canteiro de obra" afrontam partições outrora pacíficas, como aquela que separa o mundo dito animado do mundo dito inanimado. Para os pequenos, conhecer não é ser indiferente às coisas, mas estar com elas de um outro modo - desviante e canhoto. No "canteiro de obra" infantil, os objetos não ocupam um lugar assimétrico em relação às crianças. Por ser menos habituada 
às partições tecidas pelo homem na linguagem, a criança consegue abrir-se à vida secreta das coisas. Nesse sentido, são exemplares os versos do canto VIII de Invenção de Orfeu, de Jorge de Lima, nos quais uma conversa com objetos é recuperada através de um encontro imprevisto com a infância:

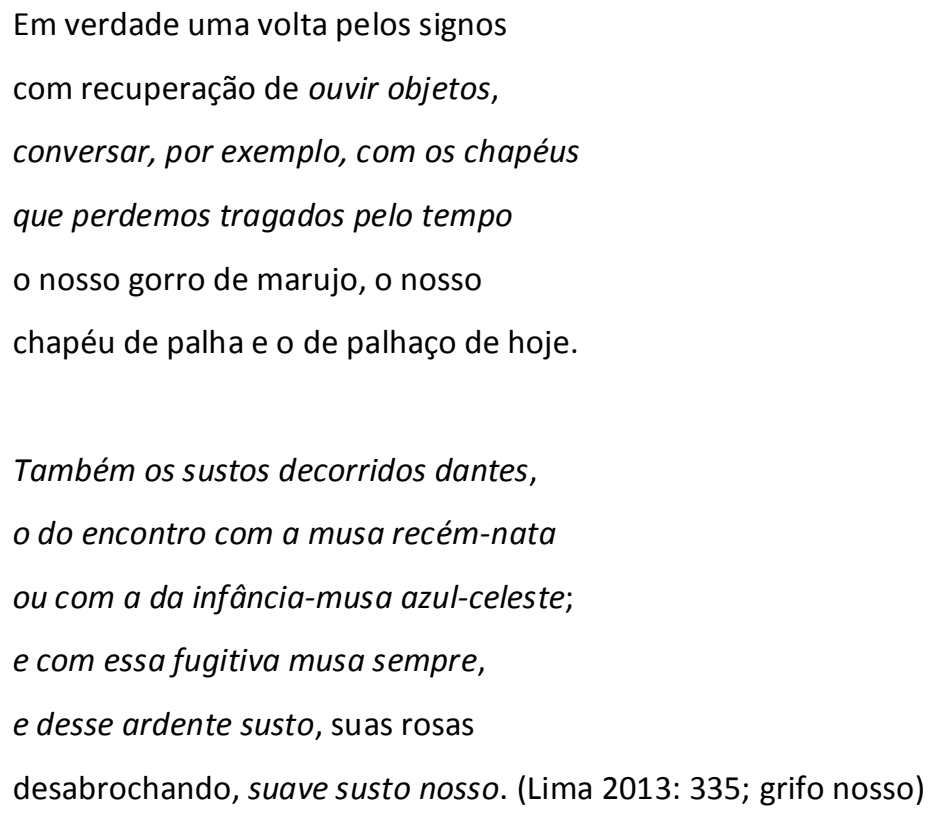

A abertura infantil ao mundo das coisas ditas inanimadas desfaz relações verticais e possibilita a criação de um mundo em devir constante, povoado por uma centena de imagens inabituais e intermitentes que circulam por toda parte, produzindo um encantamento desconcertante e resistente à decifração do sentido. Nesse espaço maravilhoso, a infância dá a mão à velhice e, juntas, promovem o encontro imprevisto de diferentes objetos, como uma máquina de costura e um guarda-chuva sobre uma mesa de dissecação, como certa vez imaginou Lautréamont.

Por operar por desvios, contradições e arbitrariedades em grau elevado, André Breton percebe afinidades entre a poética surrealista e os devaneios da infância e destaca o protagonismo da linguagem do inconsciente, da febre e do sonho nas construções inventivas do movimento francês. Por sua vez, Walter Benjamin, em ensaio de 1929 sobre o Surrealismo, considera a linguagem do movimento como autêntica quando o som e a imagem, a imagem e o som criam um amálgama refratário a explicações sobre o sentido. ${ }^{4}$ Embora não tenha participado do movimento francês, o poeta alagoano Jorge de Lima 
herda, possivelmente pela mediação de Ismael Nery, ${ }^{5}$ as lições surrealistas e, contagiado por gestos infantis, emprega surrealisticamente imagens e palavras na construção de seus experimentos verbais e visuais. Pode-se verificar esse emprego nas 41 fotomontagens reunidas no volume $A$ pintura em pânico e no poema épico Invenção de Orfeu, ambos resultantes de invenções fantásticas do poeta-em-devir-criança. A título de exemplo, veja-se a fotomontagem da mulher dormindo, à qual voltaremos na cena 3 deste trabalho, ou leiamse os versos do poema 23 do canto I de Invenção de Orfeu:

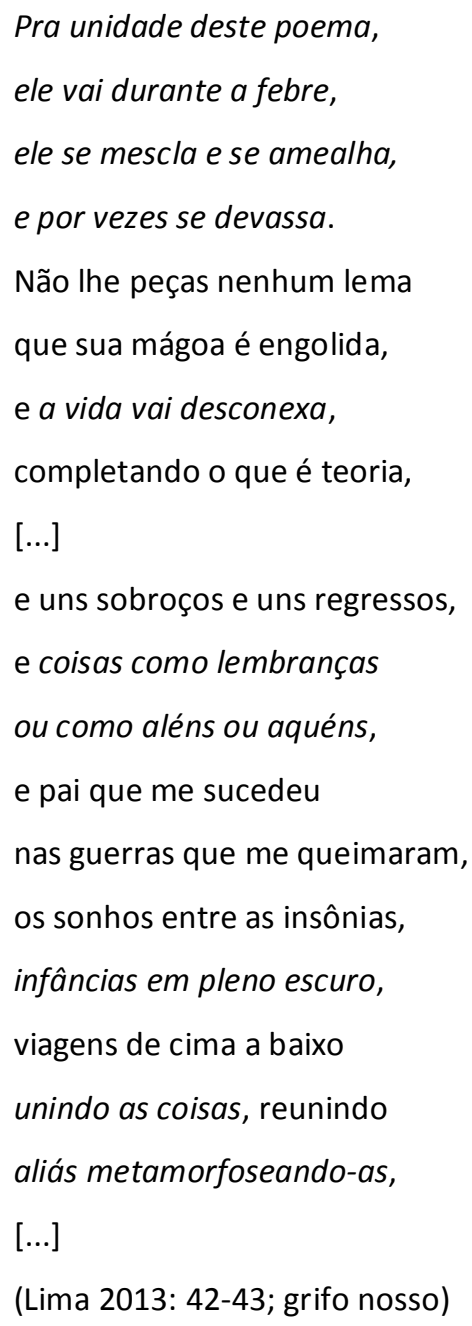

As enigmáticas fotomontagens feitas com materiais banais do cotidiano e a riqueza rítmica do poema que quer modernizar a épica seduzem e fascinam o leitor, ao mesmo tempo em que o colocam em uma encruzilhada indecidível. As imagens insólitas que proliferam das obras verbo-visuais limianas despertam a curiosidade e exigem do 
pesquisador estratégias de aproximação. Diante das obras desorientadoras de Jorge de Lima, o exercício interpretativo quer-se perspectivista e o leitor vê-se cada vez mais dependente de "intercessores" para exprimir as "potências do falso".

Impulsionados pelo andar trôpego dos bebês, que caem, levantam, voltam a cair, propõe-se, aqui, uma "escrita gaga" em torno do conceito de infância, tomando-a "para além das crianças" e entendendo-a como algo que não passa, de acordo com Jean-François Lyotard (1991: 9): “Baptisons-la infantia, ce qui ne se parle pas. Une enfance qui n'est pas un âge de la vie et qui ne passe pas. Elle hante le discours. [...] Si l'enfance demeure chez elle, ce n'est pas quoique mais parce qu'elle loge chez l'adulte." Em paralelo ao conceito de infância, busca-se pensar os experimentos verbais e visuais limianos como resultantes de uma colagem de materiais e tempos diversos feita por um devir-criança do poeta. Assim, pretende-se flagrar uma centelha do pensamento construído pela criação artística contaminada por gestos infantis.

No ensaio "O que as crianças dizem", Gilles Deleuze instaura uma linha de fuga do trabalho psicanalítico sobre as lembranças infantis e descreve a literatura como uma "cartografia dinâmica" atravessada por trajetos e devires, deslocamentos e intensidades, ao modo dos mapas traçados pela fala das crianças. Para o filósofo francês, toda literatura que apela para a infância é barata, pois a tarefa do escritor não é vasculhar os arquivos familiares nem se interessar por sua própria infância, mas, como diz em entrevista a Claire Parnet, a tarefa é "devir criança através do ato de escrever, ir em direção à infância do mundo e restaurar esta infância." 6 Não é senão este o empenho de Jorge Lima em Invenção de Orfeu quando convoca as "infâncias em pleno escuro" e a "infância-musa azul-celeste" para perseguir o conceito de poesia. Assim, interessa menos para Deleuze e Jorge de Lima a lembrança da criança que foram e mais os blocos de infância atravessando o escrever. Ao invés de vincular ou espelhar o vivido no escrito, a infância limiana desterritorializa a memória e devassa a unidade do poema, multiplicando os sons vibrantes e erráticos, como os balbucios infantis. Neste ponto em que a infância coloca a linguagem do poema em "estado de boom", a poesia diz o que as crianças dizem.

Nesse sentido, a infância é a força que efetua a tarefa de minorar a língua, de fazê-la bifurcar, gaguejar, balbuciar, porque opera por desvios e deslocamentos: “Quando a língua 
está tão tensionada a ponto de gaguejar ou de murmurar, [...] a linguagem inteira atinge o limite que desenha o seu fora e se confronta com o silêncio." (Deleuze 2011: 145) Conhecedor das possibilidades da língua, Jorge de Lima instaura na sua linguagem poética uma "gagueira criadora" que faz proliferar imagens e sons resistentes às decodificações corriqueiras, fazendo o leitor tropeçar nos versos, como uma criança que ainda não aprendeu a andar, e exigindo uma escuta para aquém das palavras. $O$ poema de abertura do canto VII de Invenção de Orfeu é exemplar sobre a concepção limiana de linguagem:

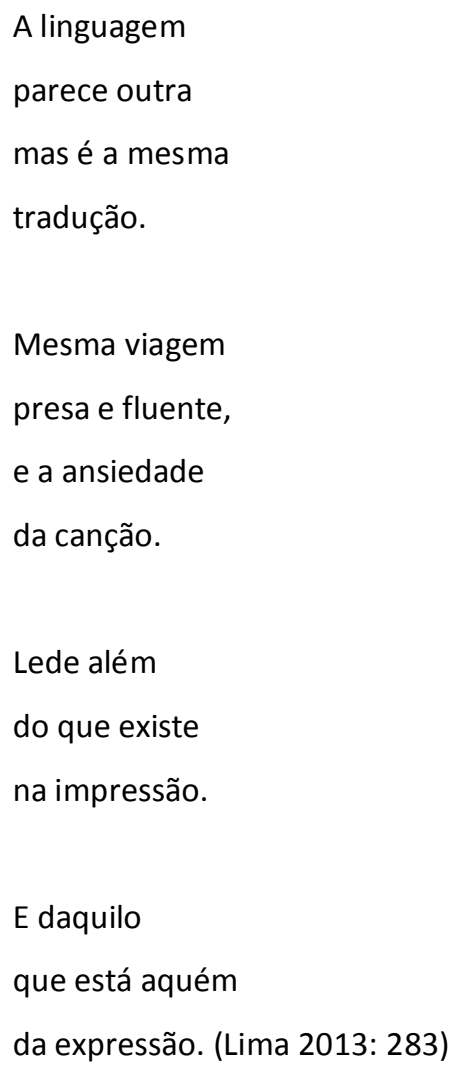

Ao uso menor da língua reivindicado por Deleuze acopla-se algo que o filósofo italiano Giorgio Agamben nomeia de experimentum linguae: a língua em sua pura autorrefencialidade, "uma experiência que se sustém somente na linguagem [...], em que aquilo de que se tem experiência é a língua em seu estado bruto" (2012a: 11). No livro Infância e História, Agamben define a infância como a dimensão originária do homem situada no hiato entre phoné e lógos, língua e discurso. Mas como falar sobre essa infância que ocorre na passagem entre experiência e linguagem se precisamos nos expropriar de nossa condição infante para nos tornarmos sujeitos? Dito de outra maneira, como falar 
sobre a infância se a condição sine qua non para tornar-se humano é a expulsão da infância que habita em nós?

Segundo Agamben (2012a), o fato de o homem ter tido uma infância, de não ter nascido na essência linguística de sua natureza, como os animais, é uma marca indelével da experiência humana em linguagem. Para aprender a falar, precisa-se fazer uma cisão irreversível: saltar do estado bruto da língua em direção ao discurso articulado. Nesse sentido, de acordo com Agamben, a aquisição da linguagem só é possível através de uma descontinuidade entre phoné e lógos, língua e discurso, sons indistintos e linguagem articulada. Mas, haveria algo que esse cair na linguagem estruturada de que fala Agamben não descartaria por completo?

Tentando recuperar a potência do balbucio, o professor de literatura Daniel HellerRoazen levanta uma hipótese interessantíssima no livro Ecolalias: sobre o esquecimento das línguas. Assim como Agamben, Heller-Roazen também opera a partir da prerrogativa de que existe um salto da experiência muda em direção ao discurso articulado. Segundo HellerRoazen, o infante, por estar mergulhado na totalidade da linguagem, possui uma capacidade articulatória ilimitada sendo capaz de produzir todos os sons de todas as línguas humanas. Apoiado nas pesquisas linguísticas de Roman Jakobson e nos estudos de Freud sobre afasia, ele enfatiza: "não há limites para o potencial fônico da vocalização infantil” (2010: 7).

Entretanto, essa habilidade fônica infinita do infante é interrompida bruscamente quando ele precisa adquirir uma língua. A perda das potencialidades ilimitadas da linguagem em estado bruto é o preço que a criança paga para adquirir uma língua específica, com um sistema fônico limitado. Diante dessa constatação inequívoca, Heller-Roazen pergunta-se o que aconteceria no intervalo entre a perda dos sons erráticos e a aquisição de uma língua determinada. A hipótese levantada é a de que as línguas dos adultos guardariam ecos desordenados dessa língua imemorial à qual somente o infante tem acesso: "seria apenas um eco, pois onde há línguas, a emissão desordenada do bebê já há muito desapareceu, ao menos na forma que uma vez possui na boca do infante que ain da não poderia falar." (2010: 9). As ecolalias retêm um eco da língua menor onde coexistem todas as línguas e na qual não se pode dizer "eu". 7 
No prefácio ao livro $O$ inumano, Jean-François Lyotard convoca essa infância indeterminada, impessoal e que persiste na idade adulta, segundo Agamben e HellerRoazen, para uma tarefa política. Por ser desprovida de palavras e estar situada no limiar entre o inumano e o humano, a infância acena com uma possibilidade ética e política de uma comunidade por vir. No intervalo entre a miséria inicial de nossa origem e a eclosão de uma língua que nos torna aptos a viver em sociedade, a infância aventura-se na tarefa intempestiva de interromper o tempo acelerado e linear dos adultos, abrindo a vida humana a experiências sensíveis que não cessam de nascer:

Desprovida da palavra, incapaz da paragem certa, hesitante quanto aos objectos do seu interesse, inapta no cálculo dos seus benefícios, insensível à razão comum, a criança é eminentemente humana, pois a sua aflição anuncia e promete os possíveis. O seu atraso inicial sobre a humanidade, que a torna refém da comunidade adulta, é igualmente o que manifesta a esta última a falta de humanidade de que sofre e o que a chama a tornar-se mais humana. (Lyotard 1997: 11)

É por estar vinculada ao nascer e às instâncias da precariedade e da inabilidade diante das coisas que a infância é um operador conceitual potente sobre as possibilidades da linguagem e o conceito de história. A incapacidade da criança de falar, entender e escrever palavras, ou sua percepção deslocada sobre o tempo lembram ao homem que ele não tem uma posição soberana diante das palavras e das coisas do mundo. Capaz de operar experiências deslocadas no tempo e na linguagem, a infância, enquanto categoria discursiva, pode renovar a experiência humana em linguagem e cindir o progresso contínuo e linear da história, de modo a impedir que ambas, linguagem e história, se apresentem como totalidade e verdade (Agamben 2005). Nesse sentido, escrever com a infância significa manter-se em constante susto diante da existência da linguagem e instaurar descontinuidades no tempo linear do progresso. Esta é, segundo Agamben e Lyotard, a tarefa da escrita e do pensamento, da literatura e das artes em geral.

Não terá sido outro o empenho de Walter Benjamin ao elaborar uma certa experiência com os rastros de sua infância berlinense. O que interessa ao pensador alemão não é resgatar um tempo idílico, nem evocar suas memórias infantis para idealizá-las, mas reler criticamente a experiência da infância na vida adulta para descobrir aí caminhos e 
passagens não percorridos, os quais ele pode retomar no presente para realizar a tarefa de escovar a contrapelo a história monumental dos vencedores. Escrevendo sobre a criança benjaminiana no limiar do labirinto, Jeanne Marie Gagnebin, estudiosa da obra do pensador alemão, destaca que as memórias infantis de Walter Benjamin não são apenas o relato da experiência da criança em uma grande cidade, mas também a reconstrução de uma memória coletiva que se transforma em objeto de análise histórico-social. Nesse sentido, as imagens infantis benjaminianas são eminentemente imagens políticas porque "o 'eu' que nelas se diz não fala somente para se lembrar de si, mas também porque deve ceder lugar a algo outro que não si mesmo." (Gagnebin 2013: 80).

Resulta desse trabalho político com a memória a insistência benjaminiana na precariedade e inabilidade infantis e sua predileção por espaços intermediários, com acessos a lugares periféricos e ermos, como a jaula da lontra ou as caves de onde se veem imagens subterrâneas dos pobres, dos vencidos e dos corcundas, enfim, de todos aqueles negligenciados pela história monumental, e aos quais a criança vai se juntar para dar voz a uma experiência coletiva maior que a do narrador. Segundo Gagnebin, a desorientação e a percepção infantis são estratégias importantes e potentes no livro de Walter Benjamin, pois, por ter um outro campo de percepção, a criança pode lançar um olhar para os invisíveis da sociedade, trazendo à superfície verdades que os adultos não querem mais ver e ouvir:

Verdade política da presença constante e subterrânea dos pequenos e dos humilhados que a criança percebe, simplesmente, porque ela mesma, sendo pequena, tem outro campo de percepção; ela vê aquilo que o adulto não vê mais, os pobres que moram nos porões cujas janelas beiram a calçada, ou as figuras menores na base das estaturas erigidas para os vencedores. (Gagnebin 1997: 180)

Por não ter uma perspectiva dominada por um sentido ou saber já codificado, a criança pode ver de outro modo os invisibilizados pela história e a linguagem. No ensaio “A doutrina das semelhanças" e nas "Imagens de pensamento", Walter Benjamin destaca esse modo de ver da criança, para quem a linguagem não é um transmissor de conteúdos e as palavras não são moedas de trocas comunicativas, mas, respectivamente, um "arquivo de semelhanças extrassensíveis" e "cavernas, entre as quais conhece curiosas linhas de comunicação" (Benjamin 2012b: 279). Percebendo potências entre materiais de campos 
semânticos distintos, a criança abre na linguagem canais de passagem por onde circulam palavras que produzem imagens e sensações resistentes à soberania de um único sentido.

Os deslocamentos semânticos acionados pelas crianças na linguagem, bem como a dimensão política ressaltada por Gagnebin nas memórias de infância de Walter Benjamin comparecem com força no soneto XXX do canto I do poema épico de Jorge de Lima, quando o poeta, escavando a ilha da linguagem, desterra da memória cenas de sua infância no Nordeste e faz uma contundente crítica social:

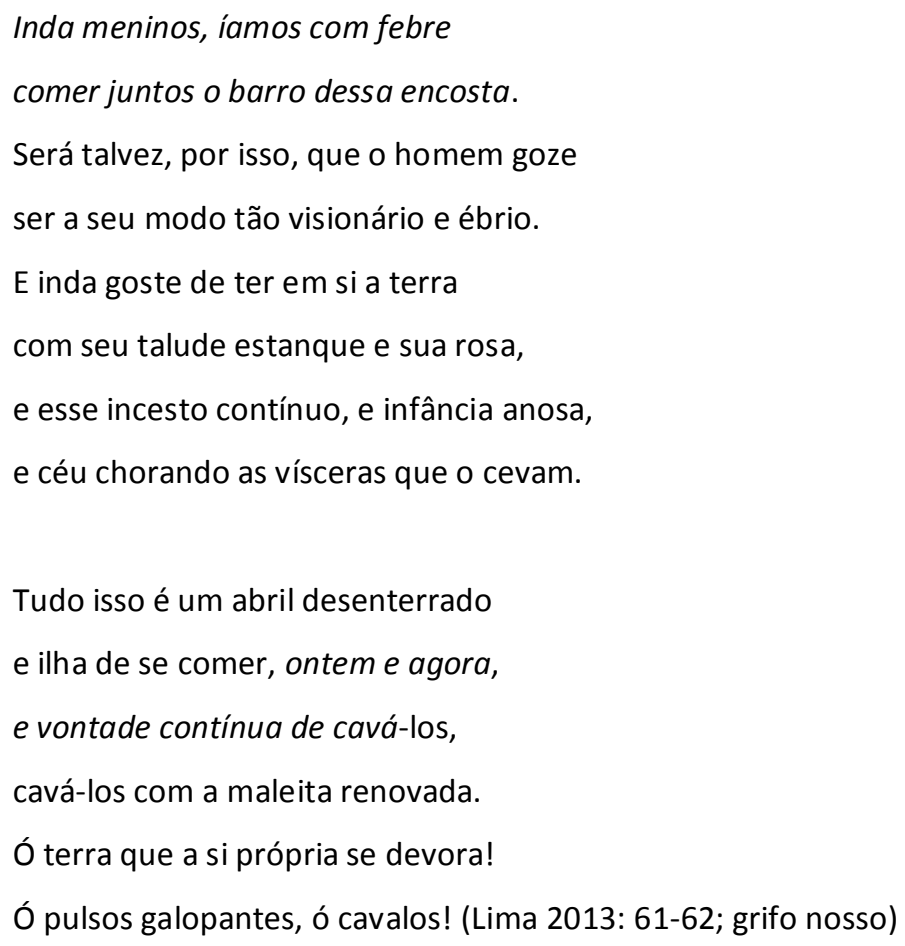

Neste soneto, o poeta resgata imagens de crianças desamparadas e impregnadas pelo real. No vácuo aberto pela expropriação do faz de conta da infância, os meninos anônimos e famintos cavam, com os delírios da febre, uma "ilha de se comer". Escrevendo com a consciência desses meninos que comeram a terra e criando uma linha de fuga das lembranças da criança que foi, Jorge de Lima dirige-se à infância do mundo e fala por todas as crianças que não puderam viver a infância.

Herdeiro da lição surrealista e ciente de que toda "infância é naturalmente fabulosa" (Bachelard 2009: 112), Jorge de Lima, no poema XXXVI do canto I de Invenção de Orfeu, potencializa através da febre a capacidade fabulatória infantil. Neste estado em que a 
sensibilidade está alterada e onde o relógio parece não ter ponteiros, ${ }^{8}$ a visão e os afetos são intensificados, potencializando um contato mais sensível com as coisas que estão ao redor. No limiar entre o sono e a vigília, a convalescença e a saúde, as coisas se avolumam e vêm até nós, expandindo o imaginário e a linguagem. Contrariando a lógica moderna de que tempo é dinheiro, a experiência da doença nos coloca em lugar precário e receptivo no qual temos tempo a perder. Como disse Charles Baudelaire, a convalescença é como um retorno à infância, porque vemos tudo como novidade, estamos sempre inebriados diante do novo. Para o poeta francês, "o convalescente goza, no mais alto grau, como a criança, da faculdade de se interessar intensamente pelas coisas, mesmo por aquelas que aparentemente se mostram as mais triviais" (2010: 25).

É a partir da mesma compreensão de Baudalaire que Walter Benjamin registra em suas memórias e Jorge de Lima em seu poema épico a experiência da convalescença. No face a face com a morte, coisas banais, como uma almofada ou a imagem de uma criança lendo, entram em um processo de metamorfose incessante, possibilitando o devir e uma abertura aos afetos. Impregnada pelos delírios da febre, a infância cria imagens em constante transformação, que atravessam as memórias benjaminianas e os versos limianos. Leia-se, em paralelo, o que dizem o pensador alemão e o poeta alagoano sobre a força imaginativa que vem da fragilidade da vida causada pela experiência da doença: ${ }^{9}$

A cada vez que uma doença se anunciava, eu aprendia sempre uma coisa: que o infortúnio tinha artes, seguras, delicadas e hábeis, de se chegar até mim. [...] Eu ficava muitas vezes doente. Daí vem talvez aquilo que todos veem em mim como paciência, mas que na verdade não corresponde a nenhuma virtude: a tendência para ver as coisas que para mim são importantes aproximarem-se de longe, como as horas se aproximavam da minha cama de doente [...] Enfim a necessidade de olhar para o futuro apoiado no tempo de espera, como um doente espera, apoiado nas almofadas que tem nas costas, teve mais tarde como consequência que as mulheres me pareciam sempre mais belas quanto mais tempo tinha de esperar por elas, confiante.

A mediação da temperatura cansava-me. Depois disso, gostava de ficar sozinho para me dedicar às minhas almofadas. Num tempo em que as colinas e os montes não me diziam ainda muito, já me eram muito familiares os cumes das almofadas. Havia uma cumplicidade 
que me ligava às forças que os fizeram nascer. Assim, por vez, dispunha-as de modo a fazer nascer nessa parede montanha uma gruta. Rastejava lá para dentro, puxava a coberta por cima da cabeça e voltava o ouvido na direção dessa garganta escura, alimentando de vez em quando o silêncio com palavras que regressavam em forma de histórias. [...] Por maiores que fossem o cuidado e o amor, não chegavam para integrar sem quebras o meu quarto na vida da nossa casa. Tinha de esperar até o anoitecer. Então, quando a porta se abria diante do candeeiro e a curva da sua chaminé oscilava na soleira e vinha ao meu encontro, era como se a esfera dourada da vida que fazia girar cada hora do dia tivesse encontrado pela primeira vez o caminho para o meu quarto, como para uma gaveta escondida. E antes de a noite se ter definitivamente instalado no meu espaço começava para mim uma nova vida; ou antes, $a$ velha vida da febre despontava para o outro sob a luz do candeeiro. O simples fato de estar deitado permitia-me tirar da luz vantagens a que outros não podiam chegar facilmente. Aproveitava o meu repouso e a proximidade da parede junto da minha cama para saudar a luz com jogos de sombras. [...] A convalescença próxima soltava, como o nascimento, ligações que a febre tinha voltado a atrair dolorosamente. E certa manhã, depois de uma longa pausa e com poucas forças, voltei a entregar-me ao som do bater dos tapetes, $[. .]$. bater dos tapetes que era o idioma das classes baixas, o verdadeiro adulto que nunca parava, não largava o trabalho [...] (Benjamin 2013: 87-91; grifo nosso).

\footnotetext{
Novamente eis que a fábula prossegue com a absorvência das forças tresbordadas 
Para levá-la as mãos do sonho arderam incandescendo a fronte despenhada [...]

Este é o curso impreciso e calendário participante e ouvido deslumbrado; a cadência do mundo o precipita numa história perdida mas lembrada, talvez despossuída, talvez nada, talvez um sabre abandonado no tempo - nosso castigo hoje e amanhã. $[\ldots]$

Também julgamos ver uma menina, que deve ser finada, penteando-se, ficamos pensativos ou folheamos à luz de uma candeia qualquer livro ilustrado com jogos malabares, [...]

enfim sendo meninos aprendemos experiências de física em família, e preparamos desde já os jogos.

As nossas mães seguram-nos os pulsos, temos febre e avistamos coisas, ou ouvimos coisas. Já começa o mundo.

Descem memórias nos constantes olhos; $[\ldots]$ coisas diversas dessas ilhas sou; o ruminado berro se transforma em pássaro de cores, cascos em ritmos de poemas, e os seus olhos olham o couro retesado soar louvores à Mão que o consolou com essa harmonia de palavras faladas sem propósito, 
tremidas pela febre, pelos medos;

[...]

e as derradeiras, só as derradeiras, como sopro de doente são ouvidas.

A imaginação dói-me. Quem ma deu, deu-ma para sofrer, para gastar-me nessas reminiscências e visões,

$[\ldots]$

Eu quero sossegar, forças rodantes, espiras, remoinhos, giros, elos, simetrias das órbitas violadas, pensamento contínuo circulando-me nas águas do passado e do futuro,

[...]

Ah! o cansaço que vem do movimento da memória insofrida e borrascosa, do pensamento alerta com a alma tonta.

$[\ldots]$

Vá que dessa danada travessia nasça a canção contínua. [...] (Lima 2013: 81-87; grifo nosso)

No fluxo vertiginoso das alucinações provocadas pela febre, as almofadas, onde estão recostadas as cabeças das crianças doentes, transformam-se em montanhas e grutas para as quais os meninos e o leitor são arrastados pelo ritmo de uma canção contínua e inebriante, feita de palavras sem propósito, balbuciadas pelos delírios da doença. Atraídos por essa força intensiva e impossível de ser contida, os ouvidos não escutam o chamado lógico do pensamento, que tenta manter-se em alerta. A cabeça rodopia, a imaginação dói e ao longe a luz intermitente das imagens fantásticas faz irromperem novas perspectivas. Ao mesmo tempo que seduzem e fascinam, as imagens, belas e enigmáticas, freiam o automatismo cotidiano e exigem do doente um deslocamento de perspectiva. Por exigirem do enfermo 
uma sensibilidade renovada diante do jogo tramado por aquilo que vemos e que nos devolve o olhar, as imagens amealhadas pela febre provocam gagueira e dores de cabeça e imaginação.

O efeito ampliado da percepção, que resulta dos delírios da febre, pode ser estendido quando se está diante das fotomontagens de Jorge de Lima. Influenciado pelo surrealismo francês, o poeta alagoano empenha-se na brincadeira infantil de recortar e colar imagens e publica em 1943 uma série de fotomontagens que, segundo Mário de Andrade, em crônica intitulada Fantasias de um poeta, podiam ser perfeitamente comparadas às de outros artistas notáveis, graças às habilidades técnica e expressiva resultantes da dedicação e do empenho do poeta.

O poeta Murilo Mendes, prefaciador do volume A pintura em pânico, onde estão reunidas as brincadeiras de Jorge de Lima com tesoura e cola, destaca, na nota liminar do livro, que as fotomontagens "são imagens de um mundo que resiste à tirania, que se aparelha contra o massacre do homem, o aniquilamento da cultura, a arte dirigida e programada."10 Poder-se-ia dizer também, na esteira das palavras murilianas, que essas fotomontagens instauram uma cisão entre o olhante e o olhado. A partir daqui, opera-se o exame das fotomontagens de Jorge de Lima em paralelo com as propostas teóricas de Georges Didi-Huberman, sobre o pensamento produzido pelas imagens visuais.

\section{CENA 3: IMAGENS EM MOVIMENTO}

No poema de abertura do canto VIII intitulado "Biografia", de Invenção de Orfeu, o poeta Jorge de Lima condensa em versos uma de suas fotomontagens mais encantadoras, segundo de Mário de Andrade, a de uma mulher dormindo que parece ressurgir da morte: “As longínquas manhãs, ó as manhãs! / as mãos no lago, sobre a tumba oculta; / e a moça adormecida se acordando / do desvaído sono gigantesco." (Lima 2013: 319; grifo nosso). 


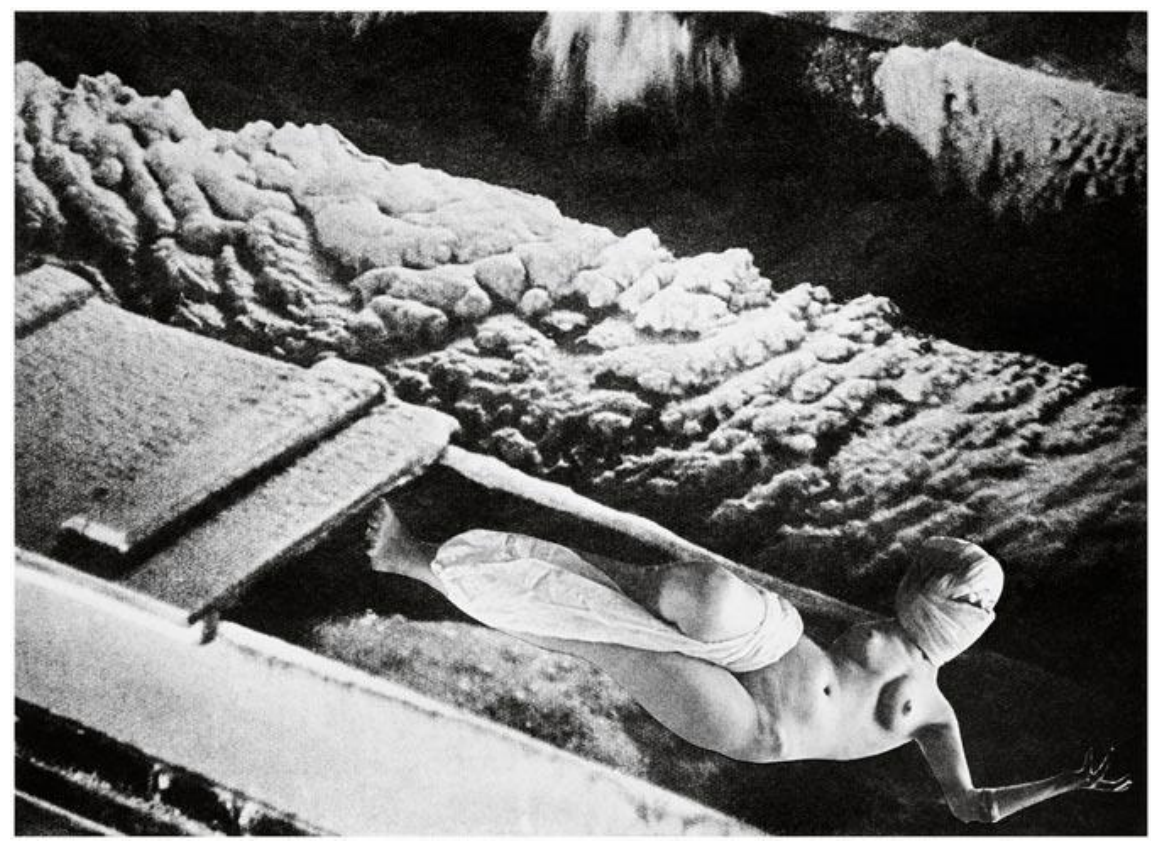

Para o exercício perspectivista que se pretende neste tópico, interessa mais o tempo de um "pós-viver" sugerido pela fotomontagem limiana do que o mote da mulher adormecida, já explorado, quase à exaustão, pelas histórias infantis. Para enfrentar o fantasma que está acordando de um "sono gigantesco", convoca-se a perspectiva teórica do filósofo e historiador da arte francês Georges Didi-Huberman. Escrevendo sobre a experiência do olhar diante de uma perda como a morte, a partir de uma passagem de Ulysses, de James Joyce, Didi-Huberman formula que "o que vemos só vale - só vive - em nossos olhos pelo que nos olha" (2010: 29). A partir dessa cisão irreversível do olhar, ele destaca duas atitudes de evitamento ou recalque da ambivalência das imagens: a crença e a tautologia. Partindo dessa constatação e baseando-se em uma rica pesquisa iconográfica, conclui que nem a posição da crença nem a da tautologia respondem ao desafio colocado pelas imagens àquele que as olha. Enquanto a atitude da crença nega o volume e a profundidade da imagem de um túmulo vazio, por exemplo, produzindo uma ficção na qual tudo subsiste em uma dimensão metafísica, a resposta tautológica, por sua vez, aferra-se somente àquilo que é visível: aquilo que se vê é apenas aquilo que se vê. Didi-Huberman situa respectivamente essas duas atitudes como um além e um aquém da cisão do ver, uma vez que ambas esvaziam as imagens, impedindo-as de criar uma trama entre o olhante e o olhado. 
$\mathrm{Na}$ contramão da resposta tautológica e a da crença e retomando criticamente a teorização de Walter Benjamin sobre a aura, mas inscrevendo-a para fora de um universo místico e inacessível, ${ }^{11}$ o historiador da arte francês empenha-se na tarefa de auratizar as imagens, Ihes concedendo força e densidade, como se fossem providas de aura. Ao retirar a transparência das imagens para dotá-las de opacidade e profundidade incontornáveis, é-se atravessado, segundo Didi-Huberman, por uma experiência ambivalente de algo próximo e exterior a nós:

Sob nossos olhos, fora de nossa visão: algo aqui nos fala tanto do assédio como do que nos acudiria de longe, nos concerniria, nos olharia e nos escaparia ao mesmo tempo. [...] 'Sentir a aura de uma coisa é conferir-lhe o poder de levantar os olhos' (Didi-Huberman 2013: 148).

Em vez de imagens a ter, imagens quase-ser. Ao atribuir às imagens um poder de olhar e deter a decodificação imediata, à maneira da pedra drummondiana, a proposta de Didi-Huberman deflaciona o homem e o coloca em um estado periclitante diante de imagens enigmáticas que não se deixam decifrar à primeira vista, como as fotomontagens de Jorge de Lima. Desse modo, para Didi-Huberman, a tensão entre olhante e olhado e seus desdobramentos - como a interrupção do automatismo que obriga o espectador a lidar com um não saber - é mais potente do que o culto ou a reverência diante de imagens e objetos "auráticos".

Também a infância pode ser pensada como uma imagem impossível de ser apreendida e decodificada, porque não é um objeto para se ter, mas algo que escapa a qualquer objetivação. A alteridade da infância frustra toda e qualquer tentativa de captura e submissão a ordens macropolíticas, pois leva o humano para um lugar gaiato onde os comandos lógicos são interceptados por uma língua repleta de balbucios, lalações e vagidos que saem da boca de seres estranhos sobre os quais nada se sabe. Segundo Jorge Larrosa (2013), a alteridade enigmática da infância em relação a nós é a presença de algo radical e irredutivelmente outro, que nos obriga a pensá-la a partir de sua absoluta heterogeneidade e diferença. A tarefa, segundo Larrosa, é abrir um lugar para receber essa infância enigmática. 
Em contato com o arquivo de Jorge de Lima, doado em 2013 ao Arquivo-Museu de Literatura Brasileira da Fundação-Casa de Rui Barbosa, a professora Marília Rothier Cardoso descobre, em meio a caixas de papéis e recortes de figuras, um livro de atas da Comissão de Literatura Infantil do Ministério da Educação, da qual Jorge de Lima participou durante os anos de 1936 e 1937. Por entender que as crianças não podem ser apreendidas pelo saber, o poeta alagoano empenha-se no exercício de abrir um lugar hospitaleiro para receber essa infância enigmática de que fala Larrosa, por meio da seleção e premiação de livros infantis de bom nível. Entrevendo aí a possibilidade de conduzir a leitura da obra limiana para a figura da infância como motivo de criação artística, Marília Cardoso abre possibilidades instigantes de pesquisa. Percorrendo o caminho aberto pela pesquisadora, buscou-se até aqui pensar os experimentos verbo-visuais limianos do lugar imprevisto da infância. Agora, deseja-se rastrear nas fotomontagens feitas pelo poeta em devir-criança a "sobrevivência" das lições de Walter Benjamin e Aby Warburg, retomadas por pensadores como DidiHuberman e Philippe Alain Michaud. Para tal exercício, propõe-se rapidamente a aproximação da proposta de Didi-Huberman em torno da imagem reauratizada e do trabalho limiano com as fotomontagens.

Contagiado por gestos infantis, Jorge de Lima vê entre as gravuras recortadas a possibilidade de construir um experimento visual não dominado por um sentido soberano, como as invenções construídas pelas crianças. No processo de seleção e colagem de suas fotomontagens, o poeta aproxima materiais precários e com tamanhos divergentes e produz entre eles choques e tensões. Por intuir que a linguagem artística, à maneira da filosofia, produz pensamento, o poeta fabrica, com a ajuda das ferramentas da infância, imagens insólitas, próximas daquelas reauratizadas por Didi-Huberman e igualmente capazes de inquirir a percepção, obrigando o olhante a lidar com a tensão resultante da aproximação de materiais díspares e incongruentes, como se pode ver nas fotomontagens abaixo: 

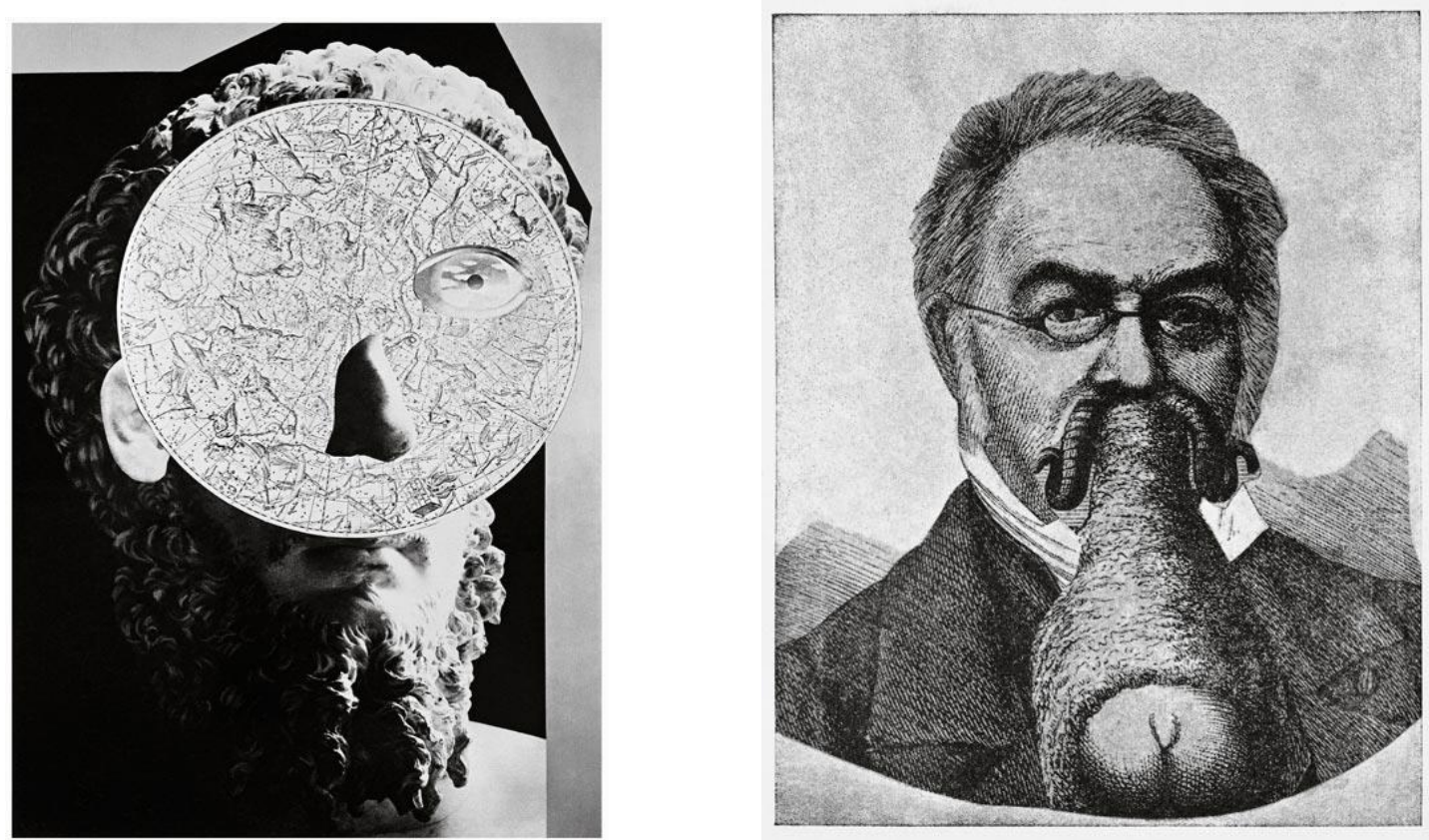

A disparidade entre os elementos recortados e colados pelo poeta em devir-criança confrontam o olhar cotidiano, provocando um curto-circuito perceptivo pela aproximação de recortes heterogêneos não harmonizados. De algum modo, Jorge de Lima está produzindo pelas imagens plásticas uma alegoria correspondente à teoria de Walter Benjamin sobre a imagem dialética, definida, segundo Agamben (2012b), por meio de um movimento carregado de tensão, "capaz de colocar um instante do passado em relação com o presente". Diante de imagens que não apaziguam os elementos, o olhante vê-se atingido por uma sensação de pânico causada pelas figuras enigmáticas, fantasmáticas ou insólitas. Liberados pela aura das imagens, os fantasmas assaltam o olhar e interrompem o pensamento corriqueiro. Empenhado na tarefa de produzir uma "pintura em pânico", Jorge de Lima salva a arte moderna do esteticismo conferindo às imagens opacidade e movimento.

Poder-se-ia dizer que a apropriação limiana de materiais populares e heterogêneos extraídos de geografias e tempos diversos, com vistas à construção de uma "pintura em pânico", guarda semelhança com o projeto do historiador da arte alemão Aby Warburg de substituir o modelo estetizante da história da arte por um modelo fantasmal da história, que se exprime por “obsessões, 'sobrevivências', remanências, reaparições das formas. Ou seja, por não-saberes, por irreflexões, por inconscientes do tempo" (Didi-Huberman 2013: 25). 
Para executar o projeto do Atlas Mnemosyne, considerado como "uma história de fantasmas para adultos", Warburg utiliza uma epistemologia interdisciplinar que desterritorializa o saber sobre as imagens e coloca em relação antropologia e história da arte. Trabalhando com resíduos da história e saberes de outras culturas, para demonstrar que as imagens não são estáticas, o historiador da arte alemão, considerado pai da Iconologia, percebe "sobrevivências" de "fórmulas do pathos" na pintura renascentista.

Deixado inconcluso, o Atlas Mnemosyne, projeto mais ambicioso de Warburg, visava construir painéis-montagem que captassem, através de uma iconologia dos intervalos, a sobrevivência de resíduos do passado arcaico na arte renascentista. Instalando movimento nas imagens, os ritos arcaicos que persistem nas formas artísticas do Renascimento retornam qual um fantasma que sai da tumba pelas brechas no túmulo do tempo cronológico. Por seu aspecto enigmático e fantasmático, que acessa blocos de infância resistentes à decodificação imediata, as brincadeiras visuais de Jorge de Lima, bem como seu poema épico do qual proliferam imagens desconcertantes produzidas por devaneios infantis, provocam no leitor que deles tenta se aproximar, assombros e balbucios, pois guardam, à maneira do atlas warburguiano, vestígios de um tempo ao qual não se pode retornar conscientemente. Só mesmo um infante, mergulhado na totalidade da linguagem, no sonho e na febre, pode percorrer os intervalos dos painéis warburguianos e as colagens poéticas e visuais inventadas por um poeta em devir-criança. 


\section{Bibliografia}

Agamben, Giorgio (2012a), Infância e História: destruição da experiência e origem da história, Tradução de Henrique Burigo, Belo Horizonte, Editora da UFMG.

-- Ninfas (2012b), Tradução de Renato Ambrosio, São Paulo, Hedra.

Andrade, Fábio de Souza (2013), Posfácio Ovo de formiga, olho do sol, Invenção de Orfeu, São Paulo, Cosac Naify, 641-659.

Andrade, Mário de (2010), Fantasias de um poeta, A pintura em pânico fotomontagens, Rio de Janeiro, Caixa Econômica Federal, 19-20.

Bachelard, Gaston (2009), Os devaneios voltados para a infância, in A poética do devaneio, Tradução de Antonio de Pádua Danesi, São Paulo, Martins Fontes, 2009.

Baudelaire, Charles (2010), O pintor da vida moderna, Tradução de Tomaz Tadeu, Belo Horizonte, Autêntica.

Benjamin, Walter (2012a), Magia e técnica, arte e política. Ensaios sobre literatura e história cultural, Tradução de Sérgio Paulo Rouanet, São Paulo, Brasiliense.

-- Rua de mão única (2012b), Tradução de Rubens Rodrigues Torres Filho e José Carlos Martins Barbosa, São Paulo, Brasiliense.

-- Rua de mão única: Infância berlinense: 1900, Tradução de João Barrento, Belo Horizonte, Autêntica.

Bines, Rosana Kohl (2012), Criar com a infância, Literatura e criatividade, Rio de Janeiro, 7Letras, 131-140.

Breton, André (2009), Manifesto do Surrealismo (1924), Vanguarda europeia e modernismo brasileiro: apresentação dos principais poemas metalinguísticos, manifestos, prefácios e conferências vanguardistas, de 1857 a 1972, Petrópolis, Vozes, 220-260.

Cardoso, Marília Rothier (2015a), "Duas lições de cartografia fantástica", Conexão Letras, no 13, <http://seer.ufrgs.br/index.php/conexaoletras/article/view/55694> (último acesso em $21 / 11 / 2015)$ 
-- (2015b), Entre os fantasmas do arquivo e o corpo da escrita, Corpos diversos: imagens do corpo nas artes, na literatura e no arquivo, Rio de Janeiro, EDUERJ, 179-194.

Chiara, Ana, Santos, Marcelo, Vasconcellos, Eliane, Corpos diversos: imagens do corpo nas artes, na literatura e no arquivo, Rio de Janeiro, EDUERJ

Compagnon, Antoine (2007), Tesoura e cola, in -- O trabalho de citação, Tradução de Cleonice P. B. Mourão, Belo Horizonte, Editora UFMG.

Deleuze, Gilles (2011), Crítica e clínica, Tradução de Peter Pál Pelbart, São Paulo, Editora 34.

Deleuze, Gilles, E de Enfance [Infância], in O abecedário de Gilles Deleuze, < http://stoa.usp.br/prodsubjeduc/files/262/1015/Abecedario+G.+Deleuze.pdf> (último acesso em 21/11/2015.

Didi-Huberman, Georges (2010), O que vemos, o que nos olha, Tradução de Paulo Neves, São Paulo, Editora 34.

-- (2013), A imagem sobrevivente: história da arte e tempo dos fantasmas segundo Aby Warburg, Tradução de Vera Ribeiro, Rio de Janeiro, Contraponto.

Gagnebin, Jeane Marie (1997), Infância e pensamento, in Sete aulas sobre Linguagem, Memória e História, Rio de Janeiro, Imago.

-- (2013), A criança no limiar do labirinto, in História e narração em Walter Benjamin, São Paulo, Perspectiva.

Heller-Roazen, Daniel (2010), Ecolalias: sobre o esquecimento das línguas, Tradução de Fábio Durão, Campinas, Editora da UNICAMP.

Larrosa, Jorge (2013), O enigma da infância, in Pedagogia profana: danças, piruetas $e$ mascaradas, Tradução de Alfredo Veiga-Neto, Belo Horizonte, Autêntica, 2013.

Leal, Bernardina de Sousa (2008), Chegar à infância, Tese, Doutorado em Educação, Universidade do Estado do Rio de Janeiro, Rio de Janeiro.

Lima, Jorge de, A pintura em pânico. Fotomontagens, Simone Rodrigues (org.), Rio de Janeiro, Caixa Econômica Federal.

-- (2013), Invenção de Orfeu, São Paulo, Cosac Naify. 
-- (2014), O mundo do menino impossível, in Antologia poética, Seleção de Fábio de Souza Andrade, São Paulo, Cosac Naify, 27-30.

Lyotard, Jean François (1991), Lectures d'enfance, França: Éditions Galilée.

-- (1997), O inumano. Considerações sobre o tempo, Tradução de Ana Cristina Seabra e Elisabete Alexandre, Lisboa: Editorial Estampa.

Mendes, Murilo, Nota liminar. < http://www.apinturaempanico.com/textos.html\#idmurilo $>$ Último acesso em 21/11/ 2015.

Nietzsche, Friedrich (2012), A gaia ciência, Tradução de Paulo César de Sousa, São Paulo, Companhia das Letras.

Olinto, Heidrun Krieger, Schollhammer, Karl Erik (org.) (2012), Literatura e criatividade, Rio de Janeiro, 7Letras,

Telles, Gilberto Mendonça (org.) (2009), Vanguarda europeia e modernismo brasileiro: apresentação dos principais poemas metalinguísticos, manifestos, prefácios e conferências vanguardistas, de 1857 a 1972, Petrópolis, Vozes.

Francisco Thiago Camêlo cursa como Bolsista FAPERJ Nota 10 o Mestrado em Literatura, Cultura e Contemporaneidade na Pontifícia Universidade Católica do Rio de Janeiro (PUCRio, Brasil). Graduou-se em Letras - Literaturas de Língua Portuguesa, pela mesma instituição, em 2014. Sua pesquisa de mestrado enfoca as relações entre infância e linguagem nas obras de Murilo Mendes e Jorge de Lima. E-mail: ftcamelo@outlook.com 


\section{NOTAS}

1 “A criança, o in-fans é primeiro aquele que não fala, portanto aquele animal monstruoso (como o dizia Lyotard), no sentido preciso de que não tem nem rugido, nem canto, nem miar, nem latir, como os outros bichos, mas que tampouco tem o meio de expressão próprio de sua espécie: a linguagem articulada." (Gagnebin 1997: 170)

${ }^{2}$ A expressão é de Deleuze\&Guattari apud Leal 2008: 18.

${ }^{3}$ Esta cena de abertura apropria-se de trechos da obra de Antoine Compagnon e Walter Benjamin e do poema "O mundo do menino impossível" de Jorge de Lima.

${ }^{4}$ Cf. Benjamin 2012a: 22-23.

${ }^{5}$ Fábio de Souza Andrade, especialista na obra de Jorge de Lima, destaca a atuação de Ismael Nery e a apropriação de aspectos da poética surrealista como fatores importantes na construção de Invenção de Orfeu:

Para que esta poesia fosse possível, não teve papel menor a apropriação de aspectos parciais da poética surrealista que teve lugar, no cenário carioca dos anos 1930, a partir das preocupações de uma vertente órfica do catolicismo, moderadamente hermética e desenvolvida à sombra da atuação de Ismael Nery, que se valeu de uma modalidade classicizada da técnica da montagem, subordinando-a a uma intenção estética unificadora e à construção de uma obra de arte individual, única, longe das intenções surrealistas. (Andrade 2013: 643)

${ }^{6}$ Cf. O abecedário de Deleuze. Entrevista a Claire Parnet realizada por Pierre-André Boutang em 1988 e transmitida a partir de novembro de 1995 pela TV-ART. Verbete "Enfance".

${ }^{7}$ As considerações entre Agamben e Heller-Roazen comparecem neste texto a partir de anotações de aula feitas durante o curso de pós-graduação “Imaginação e experiência da literatura”, ministrado pela Profa. Dra. Rosana Kohl Bines, na PUC-Rio, no segundo semestre de 2015. À Rosana, agradeço pelo diálogo sobre o conceito de infância como intensidade e pelas lições sobre ética na Academia.

${ }^{8}$ A imagem do relógio distorcido ou quebrado foi usada pelos surrealistas, como Salvador Dali e Luis Buñuel. Aqui, refiro-me ao relógio sem ponteiros do cineasta Ingmar Bergman no filme Morangos silvestres.

${ }^{9}$ Cf. "A literatura e a vida", Deleuze 2011.

${ }^{10} \mathrm{Cf}$. http://www.apinturaempanico.com/textos.html

${ }^{11}$ Cf. Didi-Huberman, 2013, p. 158-159: “Aura não é credo: seu silêncio está longe de ser apenas o discurso da crença como resposta adequada. [...] Quando Benjamin evoca a imagem aurática dizendo que, ao nos olhar, "é ela que se torna dona de nós", ele nos fala ainda do poder da distância como tal, e não um poder vagamente divino, ainda que oculto, ainda que ele mesmo diante. A ausência ou a distância não são figuras do divino [...]." 